\title{
温室メロンの育苗時における ミナミキイロアザミウマの防除
}

\author{
池田二三高・石川 毅・久保田 栄 \\ (静岡県農業試験場)
}

本種は温室メロンでは昭和 55 年以降発生し，大きな 被害をもたらしている. 温室メロンの栽培では, すで に本種の寄生した苗を定植することが多く，このため 生育初期から本種の大発生を招くことが多い。そこで 本種の無寄生苗を確保するため, 薬剤による防除法を 検討した.

\section{方 法}

温室メロンの育苗期間は，は種後から25日間である ので, 1 葉開葉期と 3 葉開葉期 (定植 5 日前) を重点 防除期と考えて薬剂処理を行い, 防除効果及び薬害に ついて検討した。

試験 I：本種の成虫・幼虫が常に温室メロン 1 葉当 り 5 頭以内の少発生の農試温室の一部を使用し, 直径 $9 \mathrm{~cm}$ 深さ $8 \mathrm{~cm}$ のポットを用い1 株ずつ育苗. 土壤は植 壤土に $10 \%$ のキノックスを混用. 品種は秋系 F 1.1982 年 9 月 15 日 1 葉開葉期, 9 月 22 日 3 葉開葉期に第 1 表 に示す薬剂を用いて，それぞれの時期に処理. 液剤は 小型スプレーを用い, 芽及び葉を十分妨す程度に散 布し，粒剤はポットの土壌表面に処理. 灌水は 1 日 1 回実施. 1 区 5 ポット反復なし。調査は 9 月 7 日, 15 日，16日，22日，23日，27日（定植相当日）に，株全 体の成幼虫数を調查. 薬害は後期の薬剂処理の影響を 確認するため, 10月 1 日まで実施.

試験 II : 本種の成虫・幼虫が常に温室メロン 1 葉当 り10頭以上の多発生の農試温室の一部を使用し育苗. 1983年 6 月 16 日 1 葉期, 6 月 23 日 3 葉期に, 第 2 表に 示す薬剤を用いてそれぞれの時期に処理. 薬剤の処理 方法, 育苗方法は試験 I と同一. 1 区 5 株反復なし. 品種は夏系 $F_{1}$ 。調査は 6 月 9 日，16日，17日，21日， 23日，24日，28日（定植相当日）に株全体の成幼虫数 を調査. 薬害調查は試験 I と同様に 7 月 2 日まで実施.

試験III：農家のメロン温室においてポット育苗し, 第 3 表の薬剤を 12 月 10 日 1 葉開葉期と 12 月 20 日 3 葉期 （定植 5 日前）に土塆表面処理し, 薬害調査を 12 月 30 日まで実施. 品種は冬系 $\mathrm{F}_{1}$.

\section{結果及び考察}

少発生時(試験 I) の散布剂による防除では, DMTP 水和剂及び BPMC 乳剂の 2 回散布で高い効果を示し たが, DPVP 乳阂では防除効果は認められなかった.
また，粒剤による防除では各薬剤とも，育苗初期，後 期のいずれの処理でも高い効果を示したが，才キサミ ル粒剂の育苗後期の処理を除いては, すべてに薬害が 認められ，初期の処理ほど著しかった。

多発生時の散布剂による防除では(試験 II ), DMTP 水和剂又は BPMC 乳剤の 2 回散布はともに効果は認 められなかった。 本た, 散布剤をDMTP 又はBPMC, 粒剂をオキサミル又はカルボスルファン又はアミノフ ラカルブとし，それぞれ育苗初期と後期に散布剂一粒 剂又は粒剂一散布剂の組合せで防除効果を検討したと ころ，初期に粒剂を後期に散布剂を用いた方が，いず れの薬剂の組合せでも防除効果は高かった。粒剤の中 では，オキサミルが他の 2 薬剤より速効的で安定した 効果を示した.

薬害については, 試験 I では, オキサミル粒剂の後 期処理を除いては全て軽微な薬害が生じた。しかし, 試験 II では, いずれも薬害は発生しなかった。試験III では, 生育初期に粒剂を 1 ポット $0.3 \mathrm{~g}$ の処理でも, 全 て薬害は生じ, アミノフラカルブ, カルボスルファン では葉縁が褐変し生育は妨げられた。 また，オキサミ ルも葉縁がやや内側に曲り, 生長はやや遅れた。 後期 に 1 ポット0.5 g の処理では,アミノフラカルブのみ葉 縁がわずかに褐変したが，汪とんど生育には影響はな いと思われた。

以上の各試験から考光, 本種が少発生の場合では, 育苗初期と育苗後期の 2 回の DMTP 水和剤1,000倍, BPMC 乳剂1,500倍の散布でも実用的な防除効果は期 待できる.しかし，多発生時には散布剤のみでは防除 効果は劣り, 粒剤を組合せた方法が有効と考号られる. この場合, 育苗初期の粒剤処理ほど防除効果は高いが (第 1 表, 第 2 表), 薬害の発生する恐れも予想される ので (第 3 表)，実用的には育苗初期にはDMTP 水和 剂1,000倍又は BPMC 乳剂1,500倍の散布を行い,さ らに育苗後期（定植 5 日前）に才キサミル粒剂，カル ボスルファン粒剤, アミノフラカルブ粒剤のいずれか を 1 ポット当り $0.5 \mathrm{~g}$ 土壤表面処理する方法が, 薬害の 発生も抑元られ，防除効果も高いものと考兄られる. また，育苗後期に粒剤処理をすることにより，定植時 には，それぞれの薬剤は吸収されているので，定植後 
から外部より飛来のある本種の成虫に対しても，防除

効果は持続することが推定される.

第 1 表 ミナミキイロアザミウマに対する各薬剤の防除効果（一区の全成幼虫数）

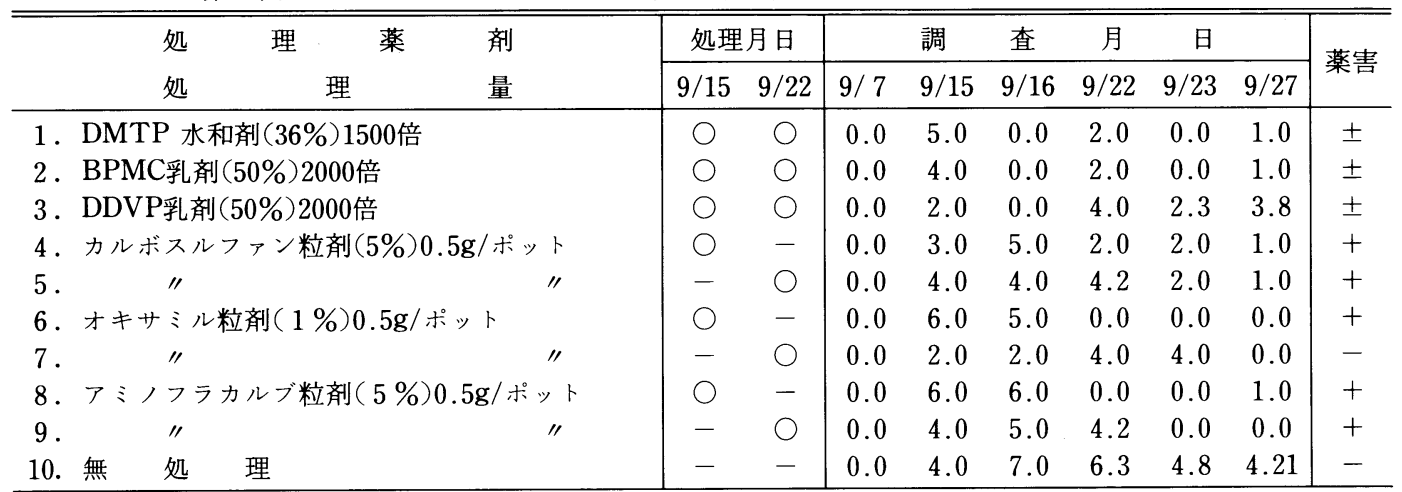

注）表中の数字は左側成虫, 右側幼虫を示す.

第 2 表 ミナミキイロアザミウマに対する各薬剤の防除効果（一区の全成幼虫数）

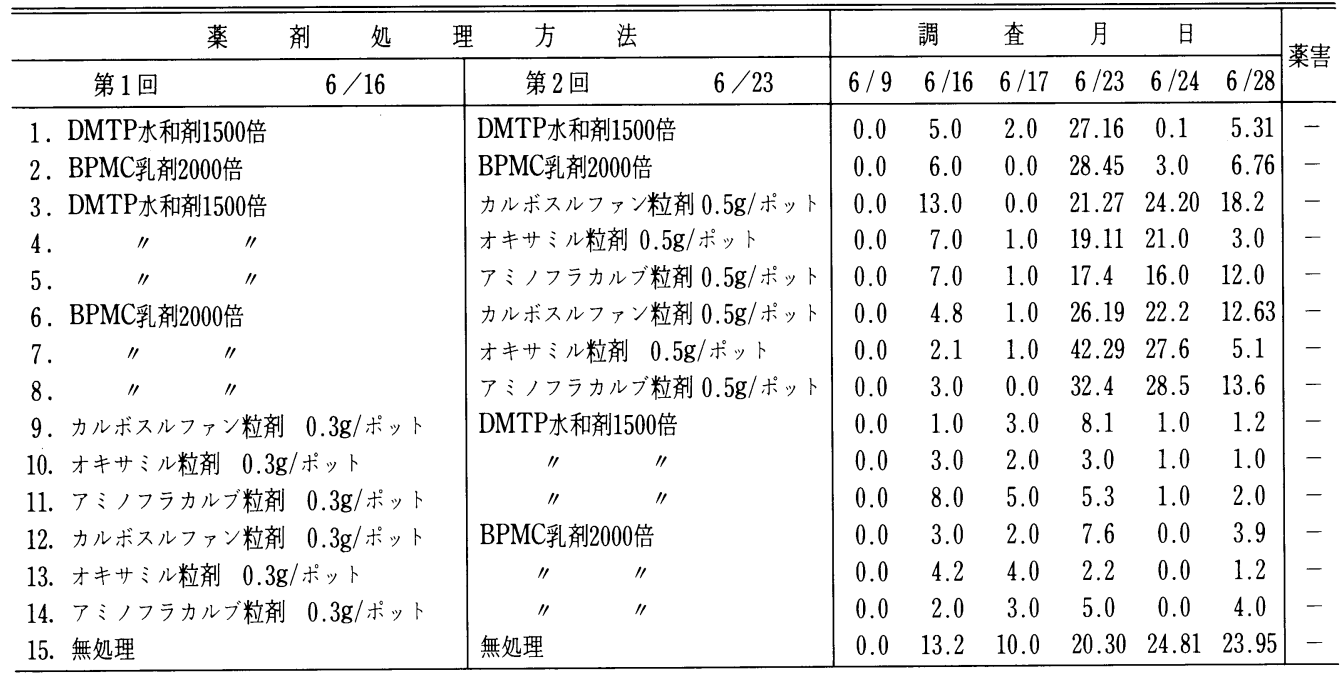

注）表中の数字は左側成虫, 右側幼虫を示す.

第 3 表 温室メロンの生育期を変えて粒剤処理をした場合の薬害

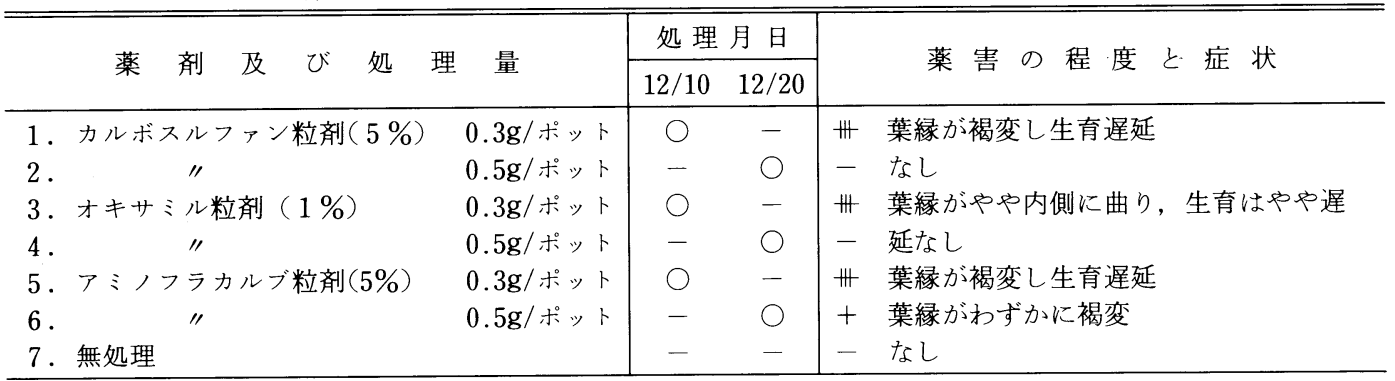

注） 12 月 10 日 1 葉開葉期， 12 月 20 日 3 葉開葉期. 